\title{
HAK PATEN TEKNOLOGI 3D FACE RECOGNITION PADA SAMSUNG
}

Putri Indah Sari

155100093

Fakultas Komputer, 448757173

Putriindahsari.student@umitra.ac.id

\begin{abstract}
Bicara soal teknologi 3D face recognition, seperti yang selama ini kita ketahui Apple merupakan vendor pertama yang mengaplikasikan fitur ini pada perangkat revolusioner iPhone X dengan nama Face ID. Setelah diperkenalkan sejak tahun 2017 lalu, sampai saat ini belum ada pabrikan smartphone lain yang berhasil menyamai performa dari teknologi ini. Sementara itu berdasarkan dari dokumen US Patent Office, teknologi pemindai wajah 3D milik Samsung diketahui sudah diajukan sejak kuartal ketiga tahun 2014. Artinya meskipun sedikit tertinggal dari Apple dalam hal perilisan, namun Samsung ternyata juga menjadi salah satu bagian dari pengembang fitur ini.
\end{abstract}

Kata Kunci : Teknologi 3D face pada samsung. 


\section{A. INTRODUCTION}

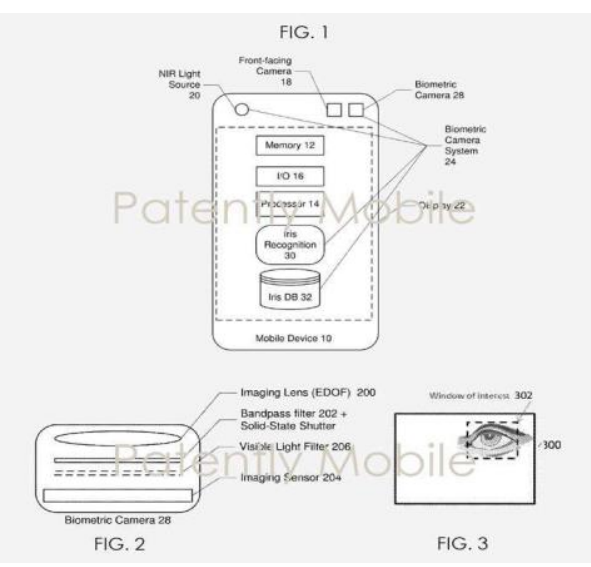

Kabar gembira bagi pengguna sistem operasi Android khususnya para penggemar setia perangkat Samsung. Pasalnya, raksasa elektronik asal Korea Selatan tersebut belum lama ini dilaporkan berhasil mengantongi hak paten terbaru dari US Patent Office, tanda kekayaan intelektual itu meliputi penggunaan teknologi pemidai wajah 3D atau 3D face scanning. Dengan adanya hak paten ini, Samsung sudah bisa menerapkan fitur canggih tersebut ke perangkat smartphone produksinya.

Bicara soal teknologi 3D face recognition, seperti yang selama ini kita ketahui Apple merupakan vendor pertama yang mengaplikasikan fitur ini pada perangkat revolusioner iPhone $\mathrm{X}$ dengan nama Face ID. Setelah diperkenalkan sejak tahun 2017 lalu, sampai saat ini belum ada pabrikan smartphone lain yang berhasil menyamai performa dari teknologi ini. Sementara itu berdasarkan dari dokumen US Patent Office, teknologi pemindai wajah 3D milik Samsung diketahui sudah diajukan sejak kuartal ketiga tahun 2014. Artinya meskipun sedikit tertinggal dari Apple dalam hal perilisan, namun Samsung ternyata juga menjadi salah satu bagian dari pengembang fitur ini.

Feature face recognition yang diperkenalkan di ponsel iPhone $\mathrm{X}$ segera mendapat tandingan, apa lagi kalau bukan sang kompetitor, Samsung. Teknologi yang berfungsi untuk mengamankan ponsel ini dirumorkan akan hadir dengan versi lebih mutakhir pada ponsel Samsung Galaxy S9 yang akan dirilis di penghujung Februari ini. 
Ini bukan kali pertama Samsung memperkenalkan feature face recognition di produknya. Sebelumnya, featureini hadir di Galaxy Note 8 yang dirilis 23 Agustus 2017. Feature ini merupakan kombinasi dari sensor wajah dan iris mata yang digadang-gadang mampu menyajikan performa maksimal walau dalam kondisi cahaya redup maupun sangat terang.

Sayangnya, ponsel berukuran bongsor itu baru disisipi feature facial recognition versi beta, sehingga kelihaiannya belum mumpuni. Terbukti dengan banyaknya keluhan dari para pengguna yang menilai sensor iris matanya cukup lambat. Performanya baru terasa lebih cepat kalau digunakan bersamaan dengan feature sensor wajah.

Lebih gawatnya lagi, face recognition di Samsung Galaxy Note 8 juga mudah diakali. Seperti dilansir CNN, tidak perlu memakai wajah asli untuk bisa lolos dari feature keamanan ini, cukup bermodal foto saja ponsel sudah bisa kebobolan. Padahal feature face recognition semestinya menjadi gerbang pengaman yang mampu memproteksi smartphone lebih tangguh dibandingkan password biasa.

Hingga saat ini, teknologi face recognition nomor wahid masih dipegang oleh iPhone X. Hadir dengan nama Face ID, sensor pengenal wajah ini tidak hanya digunakan untuk membuka akses ponsel, tapi juga sebagai metode konfirmasi pembayaran via smartphone. Sensor yang ciamik ini melengkapi kecanggihan iPhone $\mathrm{X}$, bersamaan dengan feature lainnya, seperti layar OLED Super Retina dan kamera yang lebih canggih.

Walau sempat gagal di Galaxy Note 8, Samsung tetap berkomitmen untuk menyalip posisi Apple. Seperti diberitakan laman Mashable, feature facial recognition terbaru yang akan ditanamkan di ponsel Galaxy S9 nanti akan lebih cekatan dan mampu memproteksi ponsel dengan baik. Pembaruan feature ini akan menambah keunggulan Samsung GalaxyS9 lainnya, seperti kamera depan 12MP, 
layar AMOLED yang menghadirkan gambar tajam, dan masih banyak lagi.

Samsung sudah mendapatkan akses legal untuk menggunakan teknologi 3D facial recognition layaknya iPhone $\mathrm{X}$, perusahaan tampaknya masih belum berencana membenamkan fitur ini pada perangkat terbarunya. Alihalih menyertakan pada seri Samsung Galaxy Note9 yang rencananya akan dirilis pada tanggal 9 Agustus 2018 mendatang, beberapa pihak justru berspekulasi jika fitur ini akan hadir mulai tahun depan pada seri Samsung Galaxy S10. Sebagai informasi, fitur pemindai wajah 3D besutan Samsung sendiri nantinya akan hadir dengan membawa sejumlah fungsi untuk mengurangi adanya celah keamanan, beberapa fungsi tersebut diantaranya yakni night vision, deteksi gerak, pelacakan mata, serta 3D time-offlight-sensing yang berperan mengukur lama waktu yang diperlukan pada fitur ini untuk memetakan dan membaca wajah melalui sensor. Guna mengoptimalkan sistem tersebut, Samsung rencananya juga akan menambahkan dukungan dua buah perangkat keras baru ke bagian depan ponsel untuk menangani informasi yang diterima secara internal. Perangkat itu merupakan kamera biometrik dan sumber cahaya infrared dekat.

Selain kedua hardware diatas, perusahaan juga memanfaatkan sensor kamera depan untuk menyediakan informasi terkait mata pengguna. Dalam artian, fitur pemindai wajah 3D Samsung akan mengetahui saat mata sedang terbuka, terpejam atau bahkan saat menggunakan kacamata sekalipun.

\section{B. CONCLUSION}

Samsung sudah mendaptkan akses legal untuk menggunakan teknologi 3D facial recognition layaknya iphone $\mathrm{x}$, sebagai informasi, fitur pemindai wajah 3D besutan samsung sendiri nantinya akan hadir dengan membawa sejumlah fungsi untuk mengurangi adanya celah keamanan, fungsi tersebut diantaranya yakni night vision, deteksi gerak, pelacak mata serta 3D time-of flight-sensing yang berperan mengukur lama waktu yang 


$\begin{aligned} & \text { diperlukan pada fitur ini untuk } \\ & \text { mematakan dan membaca wajah } \\ & \text { melalui } \\ & \text { sensor. }\end{aligned}$ Guna
mengoptimalkan sistem tersebut.
Perusahaan juga memanfaatkan
sensor kamera depan untuk
menyediakan informasi terkait mata
pengguna. Dalam artian fitur ini
pemindai wajah 3D samsung akan
mengetahui saat mata sedang
terbuka,terpejam atau bahkan saat
menggunkan kaca mata sekalipun.

C. ACKNOWLEDGEMENT

University Of Indonesia

University Of Mitra Indonesia

Telkom University

University Of Mellbourne

Saitama Unive

D. REFERENCE(Based ISO 690 )

[1]
A. S. Putra And O. M. Febriani,
"Knowledge Management
Online Application In Pdam
Lampung Province," In

\begin{tabular}{lrr} 
Prosiding & & \multicolumn{1}{c}{ International } \\
Conference & On & Information \\
Technology & And & Business \\
(Icitb), 2018, Pp. 181-187.
\end{tabular}

[2] A. S. Putra, O. M. Febriani, And

B. Bachry, "Implementasi Genetic Fuzzy System Untuk Mengidentifikasi Hasil Curian Kendaraan Bermotor Di Polda Lampung," J. Sist. Inf. Dan Manaj. Basis Data, Vol. 1, No. 1, Pp. 21-30, 2018.

[3] O. M. Febriani And A. S. Putra, "Sistem Informasi Monitoring Inventori Barang Pada Balai Riset Standardisasi Industri Bandar Lampung," J. Inform., Vol. 13, No. 1, Pp. 90-98, 2014.

[4] Putra, Arie Setya. "2018 Artikel Struktur Data, Audit Dan Jaringan Komputer." (2018).

[5] Putra, A. S. (2018, July 17). Paperplain Fundamental Create Application With Borland Delphi 7.0 University Of Mitra Indonesia. Retrieved From Osf.Io/Pbrn9. 


\section{E. REFERENCE $($ Based APA )}

Putra, A. S., Aryanti, D. R., \& Hartati, I. (2018, November). Metode SAW (Simple Additive Weighting) sebagai Sistem Pendukung Keputusan Guru Berprestasi (Studi Kasus: SMK Global Surya). In Prosiding Seminar Nasional Darmajaya (Vol. 1, No. 1, pp. 85-97).

Sari, D. P., Febriani, O. M., \& Putra, A. S. (2018, November). Perancangan Sistem Informasi SDM Berprestasi pada SD Global Surya. In Prosiding Seminar Nasional Darmajaya (Vol. 1, No. 1, pp. 289-294).

Putra, A. S. (2018). Paperplain: Execution Fundamental Create Application With Borland Delphi 7.0 University Of Mitra Indonesia.

Putra, A. S., Sukri, H., \& Zuhri, K. Sistem Monitoring Realtime Jaringan Irigasi Desa (JIDES) Dengan Konsep Jaringan Sensor Nirkabel. IJEIS (Indonesian Journal of Electronics and Instrumentation Systems), 8(2), 221232.
Darmawan, A., Yuliawati, D., Marcella, O., \& Firmandala, R. (2016).

Sistem Absensi dan Pelaporan Berbasis Fingerprint dan SMS Gateway. EXPLORE, 7(1).

Febriani, O. M., Wahyuni, T., \& Yusuf, S. (2017). DESIGN OF WEBSITE-BASED INFORMATION SYSTEM FOR EDOCUMENT ADMINISTRASI IN THE COMMUNITY SERVICE UNIT (A Case Study at Rajabasa District). INTERNATIONAL JOURNAL OF COMPUTERS \& TECHNOLOGY, 16(7), 7010-7020.

Febriani, O. M., \& Wahyuni, T. (2017, October). PERANCANGAN SISTEM E-DOCUMENT ADMINISTRASI LOGBOOK PENELITIAN PADA UNIT LAYANAN DI BANDAR LAMPUNG. In Prosiding Seminar Nasional Darmajaya (Vol. 1, No. 1, pp. 187-194).

Febriani, O. M., \& Permadi, A. B. (2017). Implementasi Sistem Aplikasi Data Bimbingan dan Pelanggaran Siswa pada Sekolah Menengah Atas di 
Lampung Tengah dengan Metode

Analisis dan Desain Sistem

Terdistribusi (SSAD). EXPERT, 7(1).

Febriani, O. M., \& Ambarwati, L. (2015). PERANCANGAN APLIKASI PENGOLAHAN DATA PENJUALAN UKM KELANTING KHAS TELO DESA SIDOHARJO KECAMATAN JATI AGUNG KABUPATEN LAMPUNG SELATAN. Jurnal Teknologi Informasi dan Bisnis Pengabdian Masyarakat Darmajaya, 1(1), 77-95.

Febriani, O. M. (2015). Rancang Bangun Aplikasi Ecommercemenggunakan Freewebstore pada UKM Kelanting di Desa Sidoharjo Lampung Selatan. Prosiding Sembistek 2014, 1(02), 446-458. 